\title{
HOMESCHOOLING DALAM PERSPEKTIF PENDIDIKAN ISLAM DAN UNDANG-UNDANG SISDIKNAS
}

\author{
Asrori \\ ISNU (Ikatan Sarjana Nahdlatul Ulama), \\ Jawa Tengah, Indonesia \\ asroaree@gmail.com
}

\begin{abstract}
Abstrak
Tulisan ini mengkaji tentang homeschooling dalam sudut pandang pendidikan islam dan undang-undang sisdiknas. Berdasarkan hasil analisis kepustakaan, diperoleh hasil bahwa homeschooling adalah sebuah kegiatan belajar yang dilakukan di rumah dan tidak di lembaga sekolah dengan sistem yang terprogram. Di Indonesia mempunyai pijakan yang sangat kuat yaitu berdasarkan undangundang Nomor 20 Tahun 2003 Pasal 27 termasuk pendidikan informal, dasar lain yang bisa di jadikan pijakan adalah dasar filosofi yaitu pembukaan UUD 1945 dimana pemerintah diwajibkan melindungi seluruh rakyatnya. Sedangkan homeschooling berdasarkan perspektif Pendidikan Islam mempunyai dasar dalam alQur'an dan as-Sunnah dan telah di lakukan oleh para penyebar agama Islam yang telah mendidik masyarakat Islam dengan nilainilai al-Qur'an di surau, masjid dan pondok pesantren.
\end{abstract}

Kata kunci: Homeschooling, Perspektif, Pendidikan, Islam

\begin{abstract}
HOMESCHOOLING IN THE PERSPEKTIVE OF ISLAMIC EDUCATION AND SISDIKNAS RULES. This study aims to examine about home schooling in islamic education and sisdiknas rules point of view. Based on the analysis of literature, the result showed that homeschooling is a learning activity that is done at home and not in school institutions with programmed systems. Indonesia has a very
\end{abstract}


strong foundation to hold it. That is based on Law No. 20, 2003 Article 27, including informal education. Another foundation is the basic philosophy of the opening of UUD 1945 in which the government is obliged to protect all citizens. While based on the perspective of Islamic Education, homeschooling has basis in the Qur'an and Sunnah and has been done by Muslim missionaries who have educated Islamic society with the values of the Koran in the mosque and boarding.

Keywords: Homeschooling, Perspective, Islamic, Education

\section{A. Pendahuluan}

Anak dalam Islam adalah amanah yang diberikan Allah kepada hamba-Nya untuk dididik dan dipelihara sebaik-baiknya agar kelak kalau sudah dewasa memahami dan mengerti Tuhannya, mau mengerjakan segala kewajiban-kewajiban yang dibebankannya. Allah memberikan amanat kepada kedua orang tua tidak bisa secara pemaksaan sesuai dengan kehendak orang tua, tetapi itu adalah kehendak Allah dan sekaligus kepercayaan Tuhan kepadanya. Boleh juga anak merupakan titipan Allah yang suatu saat titipan itu akan diambil oleh pemiliknya tanpa permisi kepada orang tuanya. Sebagai orang yang dititipi, harus benar-benar memberikan yang terbaik untuk merawatnya, memeliharanya dan mendidiknya.

Kemauan dan kemampuan untuk mendidik dimiliki oleh setiap orang tua. Kemampuan tersebut ditampakkan ketika ibu mulai mengandung janin yang ada dalam perut, ia selalu merawat dan menjaganya sebaik mungkin agar tidak ada masalah atau penyakit yang mengganggunya. Bahkan dalam hal makan dan minum juga ia berhatihati dan memilih-milih sesuai dengan kebutuhan si bayi. Amanat yang begitu berat inilah yang menyebabkan orang tua berusaha keras untuk memberikan pendidikan kepada anaknya dengan sebaik mungkin. Bahkan sering sekali orang tua dalam memasukkan anaknya ke sekolah selalu berpikir "nasib anakku kugadaikan pada sekolah X”. Memang benar bahwa nasib seorang anak kedepan banyak bergantung pada lembaga pendidikan yang mendidiknya. Fenomena ini yang menghantarkan orang tua berpikiran untuk menyekolahkan anaknya di lembaga-lembaga pendidikan yang favorit, karena mereka berasumsi, kesuksesan anak di masa mendatang tergantung kesuksesan anak ketika belajar di bangku sekolah. Selain amanat yang 
besar kepada orang tua, juga hasrat keinginannya untuk menjadikan anak sukses dengan kategori menjadi pejabat, orang kaya dan bermoral yang menjadikan mereka harus mencari lembaga favorit dengan ekstra. Tapi apa yang terjadi ketika mereka sudah percaya sepenuhnya kepada lembaga pendidikan, sementara anaknya tidak juga sukses sesuai dengan harapannya? Mereka akan katakan bahwa percuma saja saya membiayai anakku dengan mahal.

Sekarang ini sebagian kecil orang tua sudah mulai berkembang sebagian masyarakat yang cenderung memiliki pola pikir/mindset ketidak percayaan untuk menyekolahkan anaknya di lembaga pendidikan formal, mulai dari tingkat dasar sampai dengan tingkat atas, hal ini karena disebabkan antara cita-cita yang ia harapkan tidak sesuai dengan kenyataan. Orang tua dalam rangka mencapai kesuksesan anaknya lebih percaya pada pendidikan di rumah inilah yang dinamakan homeschooling.

Homeschooling yang telah menjamur di masyarakat, keberadaannya perlu diperhatikan, mengingat pendidikan ini sangat bermanfaat bagi generasi bangsa, dapat mendorong orang tua untuk terlibat langsung dalam mendidik anaknya. Di samping itu, dilihat dari sisi perkembangan fasilitas pendidikan yang semakin pesat dengan adanya kemajuan teknologi berupa internet maka pendidikan ini sangat memungkinkan menjadi solusi keterbelakangan masyarakat Indonesia yang selama ini selalu diberitakan.

Homeschooling adalah pendidikan informal yang diakui oleh Undang-Undang Sisdiknas Nomor 20 Tahun 2003. Pendidikan informal ini merupakan fenomena baru yang masih langka sehingga banyak orang tidak mengerti bahkan mencemooh atau bahkan menganggap anaknya di penjara di rumah, karena itu pembahasan tentang homeschooling sangat menarik untuk di bahas, apa itu homeschooling, apa dasar hukumnya, bagaimana pelaksanaannya dan bagaimana dalam pandangan pendidikan Islam? Pertanyaanpertanyaan ini akan di jawab dalam penelitian kepustakaan ini.

Dalam usaha menjawab permasalahan diatas, kajian ini menggunakan jenis penelitian studi kepustakaan. Studi kepustakaan dari sumbernya dibedakan menjadi dua bagian yaitu: kepustakaan konseptual dan kepustakaan penelitian. Kepustakaan konseptual meliputi konsep-konsep atau teori-teori yang ada pada buku-buku 
dan artikel yang ditulis oleh para ahli yang dalam penyampaiannya sangat ditentukan oleh ide-ide atau pengalaman para ahli tersebut.

\section{B. Pembahasan}

\section{Pengertian Homeschooling}

Homeschooling adalah hal yang baru berkembang di masyarakat dengan pemahaman bahwa homeschooling merupakan sebuah kegiatan belajar yang dilakukan di rumah dan tidak di lembaga sekolah dengan sistem yang terprogram.

Tidak mudah untuk mencari pengertian homeschooling, tetapai pada hakekatnya homeschooling menurut Cambridge Dictionaries Online (2015) adalah' the teaching of children at home, usually by parents'. Maksud dari kata homeschooling secara terminologi adalah pendidikan bagi anak- anak yang dilakukan rumah, khususnya dilakukan oleh orang tuanya. Selain itu, pengertian homeschooling secara istilah dapat ditemukan di dalam undang-undang Nomor 20 Tahun 2003 tentang Sisdiknas yaitu pendidikan informal yang dilakukan oleh keluarga dan lingkungan berbentuk kegiatan belajar secara mandiri dengan sistem yang terpogram yang diakui sama dengan pendidikan formal.

Sedangkan menurut (Sumardiono, 2007: 4), pengertian homeschooling adalah model pendidikan dimana sebuah keluarga memilih untuk bertanggung jawab sendiri atas pendidikan anaknya dengan menggunakan rumah sebagai basis pendidikannya. Hal ini berarti orang tua bertanggungjawab dan terlibat langsung menentukan proses penyelenggaraan pendidikan, penentuan arah dan tujuan pendidikan, nilai-nilai yang hendak dikembangkan, kecerdasan dan keterampilan, kurikulum dan materi, serta metode dan praktek belajar.

Menurut undang-undang Sisdiknas, pendidikan ini bukan merupakan lembaga formal tetapi kedudukannya sama dengan pendidikan formal baik dari sisi kegiatan belajar maupun ijazah yang dikeluarkan untuk anak didiknya. Pendidikan homeschooling dapat diakui oleh pemerintah dikarenakan cara belajarnya dengan sistem yang terpogram dan juga di atur dalam Undang-Undang Sisdiknas. 


\section{Relevansi Homeschooling dalam Sistem Pendidikan Nasional}

Supaya mengetahui ada dan tidaknya relevansi homeschooling dalam sistem pendidikan nasional maka perlu dipahami bagaimana sistem pendidikan nasional. Sistem pendidikan nasional menurut 121 Undang-Undang Nomor 20 Tahun 2003 Pasal 1 adalah, keseluruhan komponen pendidikan yang saling terkait secara terpadu untuk mencapai tujuan pendidikan nasional.

Komponen pendidikan menurut sistem pendidikan terdiri dari pendidik, tenaga kependidikan, peserta didik dan lembaga satuan pendidikan. Arti pendidik adalah tenaga kependidikan yang berkualifikasi sebagai guru, dosen, konselor, pamong belajar, widyaiswara, tutor, instruktur, fasilitator, dan sebutan lain yang sesuai dengan kekhususannya, serta berpartisipasi dalam menyelenggarakan pendidikan. Pengertian ini terlihat ada sisi kontradiksi ketika mencermati kata berkualifikasi sebagai guru ketika hal itu diterapkan dalam homeschooling, dimana orang tua yang tidak berkualifikasi sebagai guru tidak secara pasti dia sebagai pendidik.

Berkaitan dengan kualifikasi pendidik, oleh pemerintah sudah diatur dalam Peraturan Pemerintah Nomor 19 Tahun 2005 tentang Standarisasi Nasional Pendidikan Pasal 28 ayat (1) yang menyebutkan bahwa pendidik harus memiliki kualifikasi akademik dan kompetensi sebagai agen pembelajaran, sehat jasmani dan rohani, serta memiliki kemampuan untuk mewujudkan tujuan pendidikan nasional. Kualifikasi akademik yang dimaksud adalah tingkat pendidikan minimal yang harus dipenuhi oleh seorang pendidik yang dibuktikan dengan ijazah dan atau sertifikat keahlian yang relevan sesuai ketentuan perundang-undangan yang berlaku. Sedangkan yang dimaksud kompetensi sebagai agen pembelajaran pada jenjang pendidikan dasar dan menengah serta pendidikan anak usia dini meliputi : (a) Kompetensi pedagogik (b) Kompetensi kepribadian (c) Kompetensi profesional (c) Kompetensi sosial.

Pasal 29 UU Sisdiknas Nomor 20 Tahun 2003 menyebutkan bahwa kualifikasi pendidik pada pendidikan anak usia dini memiliki:

1. Kualifikasi akademik pendidikan minimum diploma empat (D-IV) atau sarjana (SI);

2. Latar belakang pendidikan tinggi di bidang pendidikan anak 
usiadini, kependidikan lain, atau psikologi; dan

3. Sertifikasi profesi guru untuk PAUD.

Pendidik pada SD/MI, atau bentuk lain yang sederajat memiliki kualifikasi sebagai berikut:

1. Kualifikasi akademik pendidikan minimum diploma empat (D-IV) atau sarjana (SI);

2. Latar belakang pendidikan tinggi di bidang pendidikan SD/ MI, kependidikan lain, atau psikologi; dan

3. Sertifikasi profesi guru untuk SD/MI.

Pendidik pada SMP/MTs, atau bentuk lain yang sederajat memiliki kualifikasi sebagai berikut:

1. Kualifikasi akademik pendidikan minimum diploma empat (D-IV) atau sarjana (SI);

2. Latar belakang pendidikan tinggi di bidang pendidikan SMP/ MTs, kependidikan lain, atau psikologi; dan

3. Sertifikasi profesi guru untuk SMP/MTs.

Pendidik pada SMA/MA, atau bentuk lain yang sederajat memiliki kualifikasi sebagai berikut:

1. Kualifikasi akademik pendidikan minimum diploma empat (D-IV) atau sarjana (SI);

2. Latar belakang pendidikan tinggi di bidang pendidikan SMA/ MA, kependidikan lain, atau psikologi; dan

3. Sertifikasi profesi guru untuk SM A/MA.

Mencermati penjabaran kualifikasi tersebut, seorang pendidik pada homeschooling hendaknya orang tua yang akan menjadi guru di rumah haruslah memenuhi syarat kualifikasi tersebut dan kalau tidak bisa memenuhinya maka harus memanggil guru untuk mendidik anaknya di rumah. Sedangkan arti tenaga kependidikan adalah anggota masyarakat yang mengabdikan diri dan diangkat untuk menunjang penyelenggaraan pendidikan. Arti peserta didik adalah anggota masyarakat yang berusaha mengembangkan potensi diri melalui proses pembelajaran yang tersedia pada jalur, jenjang, dan jenis pendidikan tertentu. Adapun satuan pendidikan adalah kelompok layanan pendidikan yang menyelenggarakan pendidikan pada jalur formal, non formal dan informal pada setiap jenjang dan jenis pendidikan. 
Sedangkan tujuan pendidikan menurut pasal (2) UndangUndang Nomor 20 Tahun 2003 bahwa pendidikan nasional berfungsi mengembangkan kemampuan dan membentuk watak serta peradaban bangsa yang bermartabat dalam rangka mencerdaskan kehidupan bangsa, bertujuan untuk berkembangnya potensi peserta didik agar menjadi manusia yang beriman dan bertakwa kepada Tuhan Yang Maha Esa, berakhlak mulia, sehat, berilmu, cakap, kreatif dan menjadi warga negara yang demokrasi serta bertanggung jawab.

Menurut pengertian dan tujuan sistem pendidikan nasional yang ada dalam undang-undang Sisdiknas Nomor 20 Tahun 2003 homeschooling sangat relevan dengan di Indonesia dan tidak bertentangan dengan perundang-undangan yang ada di Indonesia hanya saja bila orang tua tidak memiliki kualifikasi yang memadai untuk menjadi guru bagi anaknya ia harus memanggil guru untuk mengajar di rumah dan ini membutuhkan biaya yang mahal.

Relevansi homeschooling bisa dilihat juga pada sisi sejarah pendidikan di Indonesia. Homeschooling pernah juga dilakukan oleh bapak pejuang kita di zaman Belanda yaitu KH. Agus Salim. Pada saat itu orang-orang berusaha ingin bisa bersekolah di sekolah yang dikelola Pemerintah Belanda kalau sekarang SD Negeri. Pada saat itu Agus Salim menempuh jalan yang berbeda yakni mendidik anakanaknya yang berjumlah sepuluh anak di didik di rumah oleh dirinya sendiri sebagai gurunya. Baginya anak adalah sesuatu yang sangat istimewa, dia tidak ingin anak-anaknya dididik oleh orang-orang Belanda yang berbeda ideologi dengan bangsa dan agama.

Melihat sejarah tersebut homeschooling dapat dikatakan sangat relevan dengan pendidikan yang ada di tanah air dimana hal itu telah dilakukan oleh para pakar pendidikan di zaman penjajahan. Hal itu terlepas dari argumentasi Agus Salim dalam mendidik anaknya yaitu karena berbeda ideologi dan agama. Tapi yang perlu dijadikan pijakanbahwa homeschooling telah menunjukkan keberhasilan bagi anak didiknya di masa penjajahan.

Begitu juga yang dilakukan oleh pejuang kita Ki Hajar Dewantoro yang menerapkan homeschooling dalam pendidikan di Taman Siswa yang didirikan pada tahun 1922. Pendidikan menurutnya harus mencakup tiga prinsip dasar yaitu "Ing ngarso sung 
tulodho, ing madyo mangun karso, tut wuri handayani" yang artinya di depan dapat menjadi tauladan, di tengah dapat memberi bimbingan dan di belakang dapat memberi dorongan Di Taman Siswa anak di latih untuk mencari jati dirinya sendiri dengan menggali potensi yang telah di karuniakan Allah. Beliau menggunakan prinsip bahwa Allah memberikan potensi pasti sesuai dengan kebutuhan zaman dan kebutuhan individunya, karena itu ia tidak pernah membedakan anak didik itu ada yang bodoh dan ada yang pintar, semuanya sama, tinggal seberapa besar anak mampu mengolah potensi yang ada pada dirinya dan itu perlu pemantauan orang tua yang sangat ketat.

Mencermati prinsip yang digunakan oleh $\mathrm{Ki}$ Hadjar Dewantoro, homeschooling berdasarkan sejarah telah menuai kesuksesan dan hal itu sangat relevan dengan sistem pendidikan nasional sekarang ini. Dimana anak dipantau oleh orang tua secara ketat dan anak didik tidak di anggap sebagai anak yang bodoh atau juga pintar, tetapi yang penting adalah meningkatkan potensinya. Lain halnya kalau di bangku sekolah, sampai saat ini masih aja ada guru yang menganggap anak didiknya itu bodoh atau pintar. Ini merupakan kesalahan yang harus mendapat perhatian serius dari orang tua yang menyekolahkan anaknya di lembaga sekolah.

\section{Dasar Hukum Homeschooling}

Homeschooling telah mendapat kekuatan hukum yang sangat kuat dan posisi yang strategis dalam sistem pendidikan nasional, yakni telah diakomodir dalam undang-undang Sisdiknas Nomor 20 Tahun 2003. Dengan diikutsertakanya homeschooling dalam UU Sisdiknas menambah semakin jelasnya program pendidikan ini dalam melaksanakan fungsi dan tujuannya.

Berdasarkan fungsi dan tujuan pendidikan nasional yaitu pendidikan nasional berfungsi mengembangkan kemampuan danmembentuk watak serta peradaban bangsa yang bermartabat dalam rangka mencerdaskan kehidupan bangsa. Sedangkan berdasarkan tujuan pendidikan nasional yaitu bertujuan untuk berkembangnya potensi peserta didik agar menjadi manusia yang beriman dan bertakwa kepada Tuhan Yang Maha Esa, berakhlak mulia, sehat, berilmu, cakap, kreatif dan menjadi warga negara yang demokrasi serta bertanggung jawab. 
Atas dasar fungsi dan tujuan tersebut, Pasal 27 UU Nomor 20 Tahun 2003 tentang Sisdiknas mengatur homeschooling dengan menyebutnya pendidikan informal yaitu kegiatan pendidikan informal yang dilakukan oleh keluarga dan lingkungan berbentuk kegiatan belajar secara mandiri ( Ayat 1). Hasil pendidikan sebagaimana dimaksud dalam ayat 1 diakui sama dengan pendidikan formal dan non-formal setelah peserta didik lulus ujian sesuai dengan standar nasional pendidikan (Ayat 2). Ketentuan mengenai pengakuan hasil pendidikan informal sebagaimana dimaksud dalam ayat 2 diatur lebih lanjut dengan Peraturan Pemerintah.

Pasal 27 UU Sisdiknas telah meletakkan dasar yang kokoh bagi baerjalannya homeschooling di masyarakat Indonesia. Selain dasar hukum, bisa juga dijadikan pijakan dasar filosofis bahwa dalam pembukaan UUD 1945 mengamanatkan Pemerintah Republik Indonesia untuk melindungi segenap bangsa Indonesia dan seluruh tumpah darah Indonesia dan untuk memajukan kesejahteraan umum, mencerdaskan kehidupan bangsa, dan ikut melaksanakan ketertiban dunia yang berdasarkan kemerdekaan, perdamaian abadi dan keadilan sosial.

Dasar filosofis merupakan dasar yang kuat pula untuk bisa menyelenggarakan homeschooling bagi warga negara Indonesia. Hal itu terkafer dalam amanat yang menyebutkan bahwa Republik Indonesia wajib melindungi seluruh warga Indonesia dalam mencerdaskan warganya. Selain dasar filosofis, bisa juga digunakan dasar sosiologis, bahwa secara sosiologis masyarakat Indonesia telah menjalankan pendidikan dengan sistem homeschooling sejak zaman penjajahan Belanda misalnya Ki Hadjar Dewantoro dan Agus Salim. Hal ini menunjukkan bahwa homeschooling juga telah ikut memberikan peran aktifnya dan kontribusinya dalam mencerdaskan anak didik di Indonesia ini.

\section{Sistem Pelaksanaan Homeschooling}

Homeschooling sebagai pendidikan informal dilakukan di rumah dengan sistem terpogram. Terpogram disini mimiliki makna selain dilaksanakan secara systematis tetapi dalam segi materinya dilaksanakan dnegan mengacu pada kurikulum yang memadahi yang ditetapkan oleh negara. Kurikulum yang menjadi acuan dapat 
menggunakan dasar kurikulum yang telah di atur dalam Peraturan Pemerintah Nomor 19 Tahun 2005. Dijelaskan pada Pasal 6 menyebutkan bahwa:

1. Kurikulum untuk jenis pendidikan umum, kejuruan, dan khusus pada jenjang pendidikan dasar dan menengah terdiri atas:

a. Kelompok mata pelajaran agama dan akhlak mulia

b. Kelompok mata pelajaran kewarganegaraan dan kepribadian

c. Kelompok mata pelajaran ilmu pengetahuan dan teknologi

d. Kelompok mata pelajaran estetika

e. Kelompok mata pelajaran jasmani, olah raga dan kesehatan.

2. Kurikulum untuk jenis pendidikan keagamaan formal terdiri atas kelompok mata pelajaran yang ditentukan berdasarkan tujuan pendidikan keagamaan.

Sebagai contoh pembelajaran di homeschooling pada pelajaran matematika: Belajar matematika tidak hanya bisa dilakukan melalui mengerjakan latihan soal di lembar kerja. Untuk bisa mengerjakan worksheet sebaiknya anak harus terlebih dahulu diajarkan konsep dan menerapkan konsep tersebut dalam aktivitas sehari-hari. Misalkan belajar ikatan bilangan dengan menggunakan balok atau bermain congklak untuk melatih anak memperkirakan atau mengestimasi jumlah sekelompok benda. Untuk mendapatkan ide-ide mengenai mengajarkan konsep matematika untuk anak usia dini silahkan klik di internet. Di website yang dimiliki oleh Public Schools of North Carolina, kita bisa mendapatkan berbagai kegiatan menarik untuk anak belajar matematika dari mulai TK sampai dengan grade 12. Jenis kegiatannya bisa dilihat berdasarkan topik atau minggu. Bahan pendukung untuk setap permainan juga disediakan untuk diprint.

Adapun untuk mendapatkan ijazah dalam negeri kita bisa mendaftarkan anak kesalah satu komunitas homeschooling seperti "Berkemas" atau lembaga PKBM terdekat.

\section{Nilai Kompetitif dan Kelemahan Homeschooling}

Menurut Randa (2015), ada kelebihan dan kekurangan 
homeschooling. Adapun kelebihannya yaitu:

1. Pembelajaran dapat disesuaikan dengan kebutuhan anak dan kondisi keluarga

2. Kegiatan pembelajarannya bisa lebih fokus

3. Lebih memberikan peluang kemandirian dan kreativitas individual yang tidak didapatkan di sekolah

4. Memaksimalkan potensi anak SN sejak usia dini dan mengikuti standar waktu yang ditetapkan oleh homeschooling

5. Kesesuaian pertumbuhan nilai-nilai anak dengan keluarga relatif terlindung dari paparan nilai dan pergaulan yang menyimpang

6. Biaya pendidikan disesuaikan dengan keadaan orang tua, home schooling dapat menjadi alternatif bentuk layanan pendidikan bagi anak autis.

Sedangkan kekurangan homeschooling (Randa: 2005) adalah sebagai berikut:

1. Butuh komitmen dan keterlibatan tinggi dari orang tua

2. Sosialisasi dengan teman sebaya menjadi relatif rendah,

3. Anak relatif tidak terekspos dengan pergaulan yang heterogen secara sosial

4. Perlindungan orang tua dapat memberikan efek samping ketidakmampuan menyelesaikan situasi sosial dan masalah yang kompleks yang tidak terprediksi sebelumnya

5. Kematangan kepribadian anak otomatis terlambat karena jarang terpapar dengan masalah interaksi sosial.

Sekarang pilihan kembali ke kita, orang tua. Kitalah yang paling tahu apa yang paling dibutuhkan anak kita. Jangan memaksakan anak untuk mengikuti sekolah mainstream jika memang anak kita tidak mampu. Terima mereka apa adanya. Anak merupakan ciptaan Tuhan yang paling indah.

\section{Homeschooling dalam Perspektif Pendidikan Islam}

\section{a. Pengertian Pendidikan Islam}

Pendidikan dalam pengertian umum tentu pengertiannya sama dengan pendidikan konvensional, tetapi di tulisan ini yang menjadi perbedaan adalah pada kata "Islam", kata ini dalam pendidikan Islam menunjukkan suatu ciri tertentu dan anatomi tertentu dari pendidikan 
pada umumnya. Apa itu pendidikan Islam?

Pendidikan menurut Marimba (1989: 19) adalah bimbingan yang dilakukan secara sadar oleh pendidik terhadap perkembangan jasmani dan rohani anak didik agar terbentuk kepribadian yang utama. Sedangkan menurut Tafsir (2005: 45) pendidikan adalah, berbagai usaha yang dilakukan oleh seseorang pendidik terhadap anak didik agar tercapai perkembangan maksimal yang positif. Usaha itu banyak macamnya antara lain dengan cara mengajarnya yaitu, mengembangkan pengetahuan dan keterampilan anak didik. Bisa juga dilakukan dengan memberikan contoh atau tauladan dan baik juga merupakan usaha dalam mendidik anak.

Kata "pendidikan" yang umum kita gunakan sekarang, dalam bahasa Arabnya adalah "tarbiyah", dengan kata kerja "rabba". Rabba yarubbu artinya memperbaiki, menguasai, memimpin, menjaga dan memelihara. Sepadan dengan kata tersebut adalah kata "pengajaran" dalam bahasa Arabnya adalah "ta'lim" dengan kata kerjanya "'alama”. Pendidikan dan pengajaran dalam bahasa Arabnya "tarbiyah wa ta'lim" sedangkan "pendidikan Islam” dalam bahasa Arabnya adalah "tarbiyah islamiyah". Kata kerja "rabba" (mendidik) sudah digunakan pada zaman nabi Muhammad saw. (Drajat, 2000: 25). Bisa disimpulkan Tarbiyah berarti sebuah usaha menjaga dan memelihara, mengembangkan potensi berdasarkan bakat anak, dan mengerahkan segenap usaha dalam mengembangkan potensi tersebut secara bertahap untuk mencapai kesempurnaan. Pendidikan secara teoritis mengandung pengertian "memberi makan" (opvoeding) kepada jiwa anak didik sehingga mendapatkan kepuasan rohaniah, juga sering diartikan dengan " menumbuhkan” kemampuan dasar manusia. (Arifin, 1991: 32). Perlu dilihat apa saja unsur dalam pendidikan, Tafsir (2005: 32) menyebutkan bahwa unsur pendidikan adalah:

1. Menjaga dan memelihara fitrah anak menjelang dewasa

2. Mengembangkan seluruh potensi

3. Mengarahkan seluruh fitroh dan potensi menuju kesempurnaan

4. Dilaksanakan secara bertahap.

Melihat unsur-unsur tersebut, dapat diketahui bahwa pendidikan Islam adalah bimbingan yang diberikan oleh seorang pendidik 
kepada anak didiknya agar ia berkembang secara maksimal sesuai dengan ajara Islam.

Melihat makna pendidikan tersebut bahwa pendidikan secara khusus itu ada dua yaitu pendidikan rumah dan pendidikan sekolah. Di sini Islam mengakomodir dua pendidikan tersebut dan tidak hanya pendidikan sekolah saja. Karena itu ada kemungkinan sesorang untuk memilih pendidikan rumah saja (homeschooling) bisa juga memilih pendidikan formal di sekolah. Sedangkan tujuan pendidikan menurut Islam adalah membangun anak untuk bisa mengerjakan dan bertanggung jawab terhadap hidupnya di dunia dan di akherat. Dasar pengertian ini di ambil dari hadits Nabi: capailah kehidupan akhirat dengan apa yang dikaruniakan Allah tapi jangan lupa kebutuhan kehidupanmu di dunia. Dan dalam hadits yang lain: kejarlah dunia seakan kamu hidup selamanya dan berbuatlah untuk akheratmu seakan kamu besok meninggal.

\section{b. Dasar Pendidikan Islam}

Al-Qur'an merupakan dasar pendidikan Islam yang utama karena di situlah sumber-sumber nilai yang bisa diberikan oleh anak didik. Dalam al-Qur'an di jelaskan Allah akan mengangkat derajat orang-orang yang berima dan orang-orang yang berilmu beberapa tingkatan (Q.S.58:11). Ayat ini menunjukkan adanya orang-orangyang berilmu atau pendidik dan orang-orang yang mencari ilmu atau anak didik. Al-Qur'an sebagai sumber nilai perlu di kaji dan di kembangkan sesuai dengan kemajuan ilmu dan teknologi untuk kemajuan anak didik menjadi beriman, bertakwa, berakhlak mulia, cerdas, maju dan mandiri (Al-Munawar, 2005: 8). As-Sunnah merupakan dasar yang kedua setelah al-Qur'an sebagai dasar pendidikan dalam Islam. Nabi sendiri mengatakan: Tuhanku mendidikku dengan pendidikan yang mulia. Abdullah (1994: 154) menjelaskan bahwa "mendidik dan memelihara" merupakan salah satu dari sekian banyak makna implisit yang terkandung dalam kata Rabb. Di sini di gambarkan bahwa Islam dalam hal pendidikan dimulai dari al-Qur'an kemudian dari as- Sunnah.

Sistem homeschooling juga mendapat perhatian khusus dari Nabi dengan hadisnya: orang tua yang mendidik anaknya itu lebih baik dari sedekah satu mud. Hadits ini menunjukkan adanya dasar yang 
sangat kuat bagi sistem homeschooling di Indonesia bagi umat Islam.

\section{c. Sistem Pendidikan Islam di Indonesia}

Islam di bawa ke Indonesia di bawa oleh para pedagang sambil mengajarkan nilai-nilai Islam. Bahkan didikan dan ajaran Islam mereka berikah dengan perbuatan, contoh dan suri tauladan. Misalnya mereka berlaku jujur, sopan, ramah, menepati janji dan sebagainya. Ini adalah bentuk implementasi dari nilai-nilai yang mereka ajarkan yang diambil dari al-Qur'an dan as-Sunnah (Zuhairini dkk: 1997: 20). Bentuk pendidikan ini kalau kita baca sekarang kita namai pendidikan informal sebagaimana dalam undang-undang Sisdiknas Nomor 20 Tahun 2003. sekarang pendidikan informal masyarakat menyebutnya homeschooling.

Pada era awal masyarakat dididik oleh para pedagang tempatnya di surau-surau, masjid dan kemudian baru berkembang pondok pesantren. Pada awal mulanya pesantren hanya untuk mendidik anak kyai supaya pandai seperti bapaknya, kemudian masyarakat sekitar juga ikut bergabung belajar bersama pak kyai, karena rumah yang jauh mereka kemudian menginap di tempat pak kyai dan membentuk sebuah pesantren. Melihat deskripsi ini pesantren merupakan langkah pendidikan yang sama dengan homeschooling dimana kiyai mendidik anaknya di rumah sebagaimana pendidikan homeschooling sekarang dengan mendidik anak-anaknya di rumah.

\section{Simpulan}

Berdasarkan pemaparan tersebut dapat di ambil kesimpulan bahwa homeschooling di Indonesia mempunyai pijakan yang sangat kuat yaitu berdasarkan undang-undang Nomor 20 Tahun 2003 Pasal 27 termasuk pendidikan informal, dasar lain yang bisa di jadikan pijakan adalah dasar filosofi yaitu pembukaan UUD 1945 dimana pemerintah diwajibkan melindungi seluruh rakyatnya, begitu juga secara sosiologis pendidikan homeschooling juga sudah pernah di lakukan oleh para tokoh kemerdekaan Indonesia yaitu $\mathrm{Ki}$ Hadjar Dewantoro dan Haji Agus Salim. Sedangkan homeschooling berdasarkan perspektif Pendidikan Islam mempunyai dasar dalam alQur'an dan as-Sunnah dan telah di lakukan oleh para penyebar agama Islam yang telah mendidik masyarakat Islam dengan nilai-nilai alQur'an di surau, masjid dan pondok pesantren. 


\section{DAFTAR PUSTAKA}

Abdullah, Abdurrahman Saleh. 1994. Educational Theory AlQur'an Quranic Outlook. Diterjemahkan oleh H.M. Arifin dan Zainuddin. Jakarta: PT. Rineka Cipta.

Al-Baynnuni, Ahmad Izzudin. 1987. Pendidikan Anak Menurut Islam. Jakarta: Pustaka Amani.

Al-Munawar, Said Agil Husin.2005. Aktualisasi Nilai-Nilai Qur'an Dalam Sistem Pendidikan Islam. Jakarta: PT. Ciputat Press.

Arifin, M. 1991. Ilmu Pendidikan Islam Suatu Tinjauan Teoritis dan Praktis Berdasarkan Pendekatan Interdisipliner. Jakarta: Bumi Aksara.

Ashraf, Ali. 1996. Horison Baru Pendidikan Islam. Diterjemahkan oleh Sori Siregar. Jakarta: Pustaka Firdaus.

Bakri, Qosim, dkk. 1992. At-Tarbiyatu Wa Ta'lim. Ponorogo: Darussalam Press.

Cambridges Dictionary Online. 2015. Tersedia di http://dictionary. cambridge.org/dictionary/english/homeschooling. Diakses pada tanggal 27 Maret 2015.

Drajat, Zakiah. 2000. Ilmu Pendidikan Islam. Jakarta: PT. Bumi Aksara.

Marimba D, Ahmad. 1989. Pengantar Filsafat Pendidikan Islam. Bandung: al-Ma'arif.

Peraturan Pemerintah Nomor 19 Tahun 2005 Tentang Standar Nasional Pendidikan.

Randa, Valencia Mieke. 2015. Kelebihan dan Kekurangan Homeschooling. Tersedia di http://www.parenting.co.id/ dunia-mama/kelebihan+dan+kekurangan+homeschooling $+\mathrm{u}$ ntuk+abk. Diakses pada Tanggal 22 Maret 2015.

Sumardiono. 2007. Homeschooling, Lompatan Cara Belajar. Jakarta: PT. Elex Media Komputindo.

Sutrisno. 2006. Fazlur Rahman Kajian terhadap Metode, Epistemologi dan Sistem Pendidikan. Yogyakarta: Penerbit Pustaka Pelajar. 
Asrori

Tafsir, Ahmad. 2005. Ilmu Pendidikan dalam PerspektifIslam. Bandung: Penerbit PT. Remaja Rosdakarya.

Undang-Undang Nomor 20 Tahun 2003 Tentang Sistem Pendidikan Nasional.

Zuhairini dkk. 1997.Sejarah Pendidikan Islam. Jakarta: Penerbit Bumi Aksara Jakarta. 